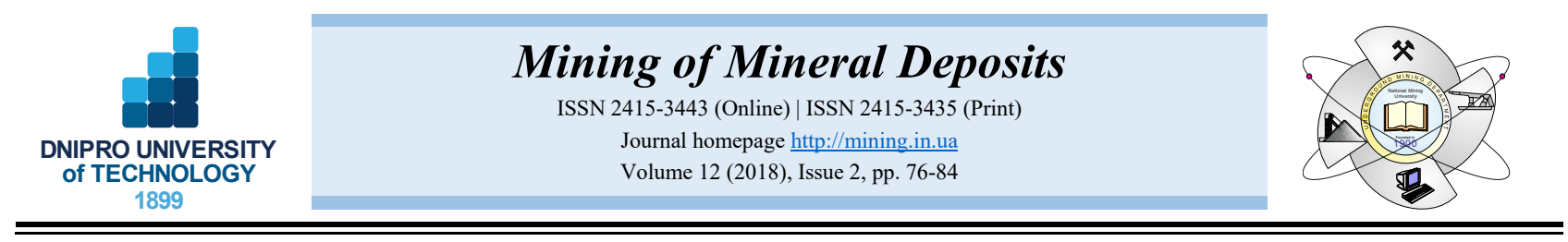

UDC 622.002.68:504.05

https://doi.org/10.15407/mining12.02.076

\title{
MODELING THE FORMATION OF HIGH METAL CONCENTRATION ZONES IN MAN-MADE DEPOSITS
}

\author{
Z. Malanchuk ${ }^{1}$, V. Korniienko ${ }^{1 *}$, Ye. Malanchuk ${ }^{1}$, V. Soroka ${ }^{1}$, O. Vasylchuk ${ }^{1}$ \\ ${ }^{\prime}$ National University of Water and Environmental Engineering, Rivne, Ukraine \\ *Corresponding author: e-mail kvja@i.ua, tel.+380501014248
}

\begin{abstract}
Purpose. To study conditions of forming the zones of high metal concentration in metal-containing man-made deposits. To assess the likelihood of metal concentration in the placer core.

Methods. Analysis of the conditions determining metal-containing placers formation and of metal losses at mining and processing plants, considering the local terrain.

Findings. It is proved that the minerals that are carried away from the separators at mining and processing plants are concentrated in the core, which contains up to $90 \%$ of heavy metals.

Originality. The studies have determined the main factors and regularities governing the distribution of heavy metals in technogenic placers, which help identify their location and calculate parameters of high metal concentration zones in the body of a man-made deposit.

Practical implications. The research has proved the possibility of using metal-containing technogenic placers, and finding the zones of maximum metal concentration on the basis of the established regularities. The authors have developed a mathematical model of the gradual formation of technogenic deposits with zones of heavy metals concentration in metal-containing waste.
\end{abstract}

Keywords: metal-containing wastes, technogenic deposit, tailing storage, hydro-mixture, consistency, metal concentration

\section{INTRODUCTION}

When mining plants are processing metal-containing raw materials, a part of valuable metals is disposed to tailing dumps, which form technogenic deposits. This waste produces a negative environmental impact and requires disposal or recycling. Technogenic deposits are also formed on the sites for the accumulation of byproducts from processing mineral raw materials or fuel, which result from losses during transportation, storage and utilization. Non-standard mineral raw materials may be processed in the future as well, given the technical and economic situation changes (Baranov, Bliuss, Semenenko, \& Shuryhin, 2006; Dychkovskyi et al., 2018).

The conditions for the formation of alluviation maps or tailing storages on the earth's surface can be diverse from the formation of cone-shaped objects on flat spots to filling gullies, ravines and lowlands. The distribution of heavy metals in such accumulations also occurs in different ways (Brahyn, 2006). Since it is expedient to involve only certain zones of technogenic deposits with the increased concentration of heavy metals to processing, there is a need to establish their location. Justifi- cation of parameters of such zones with different pulp consistency and different ways of placer formation on the site requires a systematic study (Horlytskyy, Hubina, \& Turov, 2004). There can be different options for the development of technogenic mineral resources - from partial replacer of primary mineral raw materials with waste to the creation of new production based on more efficient equipment and technology. The specified features of the technogenic mineral objects determine the corresponding tasks in geological and geo-ecological evaluation (Mohamed \& Paleologos, 2018).

Thus, it is topical to incorporate scientifically grounded technologies for ecologically safe utilization and development of metal-containing technogenic placers.

\section{LITERATURE REVIEW AND PROBLEM STATEMENT}

At present, technogenic placers are beginning to gain importance as an independent industrial type of deposits. It is predictable that in future, with the depletion of the mineral-raw base, their role will only grow. This group of placer deposits has always attracted attention, because

C 2018. Z. Malanchuk, V. Korniienko, Ye. Malanchuk, V. Soroka, O. Vasylchuk. Published by the Dnipro University of Technology on behalf of Mining of Mineral Deposits. This is an Open Access article distributed under the terms of the Creative Commons Attribution License (http://creativecommons.org/licenses/by/4.0/),

which permits unrestricted reuse, distribution, and reproduction in any medium, provided the original work is properly cited. 
even those small though positive attempts to explore the placers that were previously worked out, indicate their significant potential and prospects. At the same time the reserves with quite low metal content can be costeffective for processing (Baiysbekov, Ospanova, \& Mozgovyh, 2006; Lozynskyi, Saik, Petlovanyi, Sai, \& Malanchyk, 2018).

The Cadastral Accounting Office with the Geological Service of Ukraine has registered more than 1500 objects of the main types of industrial waste accumulation. However, among them there are only 13 objects with the status of technogenic placer deposits of which one is being developed, three are ready for the development, while others are conventionally classified as potential deposits and man-made phenomena (Haletskyy, Petrova, $\&$ Polska, 2004). The indicated accumulations of waste contain an increased content (at the level of ore deposits or above) of a number of metals, such as scandium, gallium, yttrium, germanium, tantalum, niobium, mercury, lead, zinc, copper, vanadium, zirconium, gold, silver, etc. According to the Geological Service of Ukraine, these metals are not extracted because of the absence of technology for the technogenic placers development.

The increased concentration of metals $(\mathrm{Fe}, \mathrm{Cu}$, Ti, $\mathrm{Co}, \mathrm{Pb}$ ) is identified in mine waters around the area of the Parys Mountain copper deposit (England, North Wales) (Bullock, Parnell, Perez, Feldmann, \& Armstrong, 2017). However, it should be noted that this paper does not discuss peculiarities of the increased metalconcentration zones formation and the technology of extraction. This means that there is no commonly acceptable idea about the process of technogenic placers formation and the regularity that affects the distribution of metals in sites of their high concentration. In order to solve this problem, the study (Malanchuk, Malanchuk, Korniyenko, \& Ignatyuk, 2017) presents the formation of the technogenic placer of the cone-shaped tuff on a horizontal plane. The regularity of the heavy metals core formation with the percentage content up to $80 \%$ is defined. It is shown that due to the established analytical dependence it becomes possible to use technogenic placer of conical type for copper mining. It is concluded that there is a necessity to conduct a research in order to detect the concentration of valuable metals in the formation of man-made placers in gullies, ravines, and lowlands. The expediency of using and recycling industrial waste collected in gullies and ravines, at the Chelyabinsk zinc plant (Russia) (Bryantseva \& Dubanov, 2011) is confirmed by the scientists of the Ural Branch of the Russian Academy of Sciences. The research has proved high efficiency of the investment project for the processing of industrial waste and zinc electroplating. It is necessary to conduct the study on the detection of metals percentage in the waste and assess the damage caused thereof in order to resolve environmental problems of the metallurgical complex.

Under these specific circumstances, China has developed a program for the restoration of landscapes littered with waste from mining enterprises (Yan-xia, 2016). Multidisciplinary research into disposal and recycling of metal-containing waste from Dabaoshan Mine in Guangdong Province has been carried out.
According to the data of mineral raw materials analysis (Wang, Zhang, Zou, Wang, \& Yu, 2015), a considerable amount of metals has been accumulated in the waste, which requires additional study with a view to their extraction. At mining and processing plants in Ukraine, Russia, Kazakhstan, and Uzbekistan (Naduty, Malanchuk, Malanchuk, \& Korniyenko, 2016), minerals processing leads to intensive contamination of large areas with waste. Metallization begins to affect living organisms, including humans. The authors of (Dyusembaeva \& Akkazyna, 2017) believe that investigation of ecological and technological aspects of processes concerned with the formation of technogenic placers containing valuable metals requires additional research related to their industrial development. The problems of the formation and use of tailing storages in the areas with complex terrain are also stu-died in such European countries as Serbia (Dozic et al., 2010), Turkey (Onuaguluchi \& Eren, 2012), and Romania (Levei, Frentiu, Ponta, Tanaselia, \& Borodi, 2013). The potential ecological hazards of tailing storages formed as a result of noble and non-ferrous metals treatment have been investigated. The multi-factor studies of rare earth metal waste (Jha et al., 2016) identified hazardous metals (fluorine, sulfates, $\mathrm{Cu}, \mathrm{Ni}, \mathrm{Pb}, \mathrm{Zn}$ ), which are harmful to living organisms and cause soil contamination. The program of long-term monitoring of rare earth waste accumulation sites, environmental protection and advanced studies on the concentration of heavy metals in waste has been developed.

The urgent scientific and applied task of extracting rare earth metals and reducing the amount of waste at mineral processing facilities is very topical in Spain (Cánovas, Macías, Pérez López, \& Nieto, 2018). Solving the problem of recycling metal-containing waste will increase the environmental safety of the territory, while an enterprise will economically benefit from partial or complete replacement of primary mineral raw materials with waste.

To conclude, since the formation of zones with increased metal-content in metal-containing waste has been studied insufficiently, there is an urgent need to further research in this field.

\section{AIM AND TASKS OF THE RESEARCH}

The aims of the research were to establish the quantitative distribution of useful components in the formation of technogenic placers on a site with complex relief depending on the local landscape; to experimentally determine the parameters of zones with high concentration of heavy metals; to identify the location of placers "cores" for the purpose of extracting valuable minerals for the enhancement of environmental safety.

To achieve this goal the following tasks were resolved:

- to investigate the process of technogenic placers formation with different concentrations of hydromixtures and to establish regularities that affect the parameters of heavy metals concentration zones in placers;

- to determine the percentage of metals in places of their high concentration, depending on the local terrain. 


\section{THE MATERIALS AND METHODS OF THE RESEARCH}

The research has been conducted on a model in laboratory conditions using volcanic tuff from the Rafalivsky quarry (Ukraine), which contains from $0.4 \%$ to $1.2 \%$ of native copper. Experimental samples of tuff flour were prepared after crushing the rock on a grinding mill. The granulometric composition of the crushed tuff contains particles of the size $>2.0 \mathrm{~mm}-28 \%$; $1.0-2.0 \mathrm{~mm}-30 \% ; 0.5-1.0 \mathrm{~mm}-8 \% ; 0.25-0.5 \mathrm{~mm}-$ $16 \% ; 0.1-0.25 \mathrm{~mm}-10 \% ;<1.0 \mathrm{~mm}-8 \%$ of the total mass of the material. Freshly mined tuffs are fairly cemented, but under the impact of moisture (water regain $36 \%$ ) they decay to form a loose mass with plasticity index of $5-7$ and porosity $-30 \%$. Tuff has the following characteristics: water absorbing capacity by weight $18 \%$; water absorption by volume - $33 \%$; strength $5 \mathrm{MPa}$; bulk density $1.0-1.2 \cdot 10^{3} \mathrm{~kg} / \mathrm{m}^{3}$, specific surface $120 \mathrm{~m}^{2} / \mathrm{kg}$. The chemical composition of tuff as determined by spectral analysis, comprised: $\mathrm{SiO}_{2}-47.2 \%$; $\mathrm{TiO}_{2}-1.98 \% ; \mathrm{Al}_{2} \mathrm{O}_{3}-13.9 \% ; \mathrm{Fe}_{2} \mathrm{O}_{3}-11.9 \% ; \mathrm{FeO}-1.7 \%$; $\mathrm{MnO}-0.17 \% ; \mathrm{MgO}-7 \% ; \mathrm{CaO}-2.79 \% ; \mathrm{Na}_{2} \mathrm{O}-4.87 \%$; $\mathrm{K}_{2} \mathrm{O}-1.48 \% ; \mathrm{P}_{2} \mathrm{O}_{5}-0.14 \% ; \mathrm{SO}_{3}-0.03 \%$.

For the purpose of the study, the hydro-mixture was prepared in the electric mixer (used for preparation of sand-lime solutions with volume of $0.75 \mathrm{~m}^{3}$ ). The mixer was loaded with portions of tuff, water and metal with different consistency of water in respect to tuff (liquid to solid) $\mathrm{L}: \mathrm{S}$ and different content of native copper. When applying hydraulic methods for the enrichment of mineral raw materials, the optimal ratios of $\mathrm{L}: \mathrm{S}$ are $80 \%$ to $20 \% ; 85 \%$ to $15 \% ; 90 \%$ to $10 \%$. The stopwatch was started as soon as the first portion of the hydromixture appeared at the outlet of the pulp line and it was switched off at the time of the transportation halt, which allowed to average hydraulic parameters of hy- dro-mixture flow in the formation of technogenic placers. The percentage of native copper in experiments was taken at the rate of $0.5,0.75,1.0 \%$ in relation to the tuff weight. Since in tuffs, copper occurs in fine impregnations with diameters up to $2 \mathrm{~mm}$, the size of metal balls used in experiments was in the range from 1 to $2 \mathrm{~mm}$. The investigated zeolite-smectite tuff has a significant water absorption capacity (up to 30\%), hence, it gets crumbled during hydrotransportation.

The main attention in modeling technogenic placers formation was paid to maintaining the regime of the hydro-mixture issue from the pulp line, as well as to achieving the given concentration of the tuff hydromixture in the mixer. To ensure the necessary accuracy in determining the percentage content of metal in a laboratory-built technogenic placer, the latter was divided into separate sections of $10 \times 10 \times 5 \mathrm{~cm}$. These samples were placed on the test table, and then the metal was removed by means of a magnetic rod separator of SMC 0.5-1-MN-0.2 type with magnetic induction of $600 \mathrm{mTl}$. The extracted metal was weighed on the electronic scales: VLKT make - $500 \mathrm{~g}-\mathrm{M}$ and VLKT $2 \mathrm{~kg}-\mathrm{M}$. It does not seem possible to give a quantitative estimation to energy consumption in the pulp incident flow separately for each solid particles interaction in the plunge pool. In the studies, we used the method of the total estimation of the hydro-mixture flow work, which was defined as the maximum transporting capacity of the incident flow in the placer body. The simulation was based on the hydraulic size, which takes into account the effect of gravity and inertia forces on the sedimentary rock during alluviation. The process of technogenic placer formation with the core was investigated depending on the concentration of hydro-mixture - in three series of 27 experiments listed in Table 1.

Table 1. Basic methodological indicators of experimental research

\begin{tabular}{|c|c|c|c|c|c|c|}
\hline \multirow{2}{*}{ Experiment No. } & \multirow{2}{*}{$\begin{array}{c}\text { Time, } t, \\
\min \end{array}$} & \multirow{2}{*}{$\begin{array}{l}\text { Volume of } \\
\text { water, } W, 1\end{array}$} & \multirow{2}{*}{$\begin{array}{c}\text { Mass of tuff, } \\
\qquad, \mathrm{kg}\end{array}$} & \multicolumn{3}{|c|}{ Mass of metal, $m, \mathrm{~kg}$} \\
\hline & & & & $0.5 \%$ & $0.75 \%$ & $1.0 \%$ \\
\hline \multicolumn{7}{|c|}{ Series 1} \\
\hline 1 & 27.7 & 90 & 10 & 0.050 & 0.075 & 0.10 \\
\hline 2 & 26.8 & 90 & 10 & 0.050 & 0.075 & 0.10 \\
\hline 3 & 26.0 & 90 & 10 & 0.050 & 0.075 & 0.10 \\
\hline \multicolumn{7}{|c|}{ Series 2} \\
\hline 4 & 28.8 & 85 & 15 & 0.075 & 0.1125 & 0.15 \\
\hline 5 & 27.4 & 85 & 15 & 0.075 & 0.1125 & 0.15 \\
\hline 6 & 27.8 & 85 & 15 & 0.075 & 0.1125 & 0.15 \\
\hline \multicolumn{7}{|c|}{ Series 3} \\
\hline 7 & 24.2 & 80 & 20 & 0.1000 & 0.1500 & 0.20 \\
\hline 8 & 24.6 & 80 & 20 & 0.1000 & 0.1500 & 0.20 \\
\hline 9 & 24.9 & 80 & 20 & 0.1000 & 0.1500 & 0.20 \\
\hline
\end{tabular}

After crushing in the sledger, the tuff portions of 10 , $15,20 \mathrm{~kg}$ and the water portions of $90,85,801$ were loaded into the mixer model for the preparation of hydromixtures. The model tuff mixture was freshly prepared for each experiment - the alluvial tuff was not used for subsequent experiments. The consistency of the hydromixture was established in the $\mathrm{L}: \mathrm{S}$ range from 10 to $20 \%$ and created in the surge tank as a result of the selection of the required pulp mixer revolutions for the studied model composition of the tuff. The consistency of the hydro-mixture from 10 to $15 \%$ corresponds to the production conditions of tailing dumps at mining enterprises. In the studies, the $\mathrm{L}: \mathrm{S}$ ratio was established at $80 \%: 20 \%$ purely for experimental purposes. In production conditions such $\mathrm{L}: \mathrm{S}$ ratio can be achieved using thickeners. After the completion of soil hydraulic deposition in the tray and its consolidation during one day, the following parameters were measured: the slope of the 
sediments, the height of the dump, the percentage of metal in the dump body and the length of the deposition base.

Since for financial reasons it was impossible to conduct the experiment simulating filling of the low-lying placers, the corresponding data are not provided in the findings.

\section{RESULTS OF THE RESEARCH INTO THE FORMATION OF ZONES WITH INCREASED METAL CONTENT}

The paper proves that the minerals contained in the incident flow of hydro-mixtures or washed from apron plates of ore-mining enterprises concentrate in the so-called "core". It also presents a detailed description and the experimental data related to the process of pulp issuance from the pulp line, its fall on the sloping plane and the formation of the placer with the core containing up to $90 \%$ of heavy metals.
To substantiate this supposition, the simplified technological schemes describing the process of man-made placers formation in ravines and gullies are considered. The shape of the heavy metals concentration zone and the percentage of metal content in it are established (Tables 2-5, Figs. 1-3).

The hydro-mixture is transported along the pulp line to the alluviated tailings storage facility where it flows to the bottom under pressure or gravity. The pulp line is located in the corner of the pit, or as close to it as possible, ensuring the safety requirements. The flux from the pulp line falls on the slope to be further spread on the bottom of the ditch.

Comparison of experimental data on the metal content in the placer core for the investigated consistencies of hydro-mixture and the corresponding percentage of metal content in it are given in generalizing Table 5.

Table 2. Average metal content in technogenic placers formed in ravines and gullies with the consistency of the tuff hydro-mixture of $L: S / 90 \%: 10 \%$

\begin{tabular}{cccccc}
\hline \multirow{2}{*}{ No. } & $\begin{array}{c}\text { Length of placer, } \\
L, \mathrm{~m}\end{array}$ & \multicolumn{3}{c}{$\begin{array}{c}\text { Average mass of metal } \\
\text { in the core, } \mathrm{g}\end{array}$} & $\begin{array}{c}\text { Height of the } \\
\text { dump, } H, \mathrm{~m}\end{array}$ \\
\cline { 3 - 5 } & 0 & $m_{1} 1.0 \%$ & $m_{2} 0.75 \%$ & $m_{3} 0.5 \%$ & 3.00 \\
\hline 1 & 3 & 15.46 & 2.65 & 2.49 & 2.75 \\
2 & 6 & 32.70 & 16.6 & 7.18 & 2.50 \\
3 & 22.51 & 15.57 & 9.8 & 2.00 \\
4 & 9 & 7.98 & 7.54 & 5.9 & 1.75 \\
5 & 12 & 6.47 & 5.78 & 5.51 & 1.50 \\
6 & 15 & 3.84 & 2.65 & 2.28 & 1.25 \\
7 & 18 & 0.00 & 0.00 & 0.00 & 1.00 \\
8 & 21 & 0.00 & 0.00 & 0.00 & 0.70 \\
9 & 24 & 0.00 & 0.00 & 0.00 & 0.50 \\
10 & 27 & 0.00 & 0.00 & 0.00 & 0.25 \\
11 & 30 & 0.00 & 0.00 & 0.00 & 0.12 \\
12 & 33 & 0.00 & 0.00 & 0.00 & 0.00 \\
13 & 36 & 0.00 & 0.00 & 0.00 & 0.00 \\
14 & 39 & 0.00 & 0.00 & 0.00 & 0.00 \\
15 & 42 & 0.00 & 0.00 & 0.00 & 0.00 \\
16 & 45 & 0.00 & 0.00 & 0.00 & 0.00 \\
17 & 48 & 92.96 & 60.25 & 43.35 & - \\
$\Sigma$ & - & & & & \\
\hline
\end{tabular}

Table 3. Average metal content in technogenic placers formed in ravines and gullies for the consistency of tuff hydro-mixture $L: S / 85 \%: 15 \%$

\begin{tabular}{cccccc}
\hline \multirow{2}{*}{ No. } & $\begin{array}{c}\text { Length of placer, } \\
L, \mathrm{~m}\end{array}$ & \multicolumn{3}{c}{$\begin{array}{c}\text { Average mass of metal } \\
\text { in the core, } \mathrm{g}\end{array}$} & $\begin{array}{c}\text { Height of the } \\
\text { dump, } H, \mathrm{~m}\end{array}$ \\
\cline { 3 - 5 } & 0 & 4.89 & 3.80 & 2.81 & 4.50 \\
\hline 1 & 3 & 30.60 & 18.90 & 12.05 & 3.75 \\
2 & 6 & 48.40 & 33.40 & 21.25 & 3.50 \\
3 & 9 & 28.13 & 16.98 & 11.31 & 3.25 \\
4 & 12 & 14.50 & 14.90 & 8.34 & 3.00 \\
5 & 15 & 11.73 & 12.25 & 8.51 & 2.50 \\
6 & 18 & 6.46 & 6.22 & 3.06 & 2.00 \\
7 & 21 & 0.00 & 0.00 & 2.06 & 1.50 \\
8 & 24 & 0.00 & 0.00 & 0.00 & 0.50 \\
9 & 27 & 0.00 & 0.00 & 0.00 & 0.30 \\
10 & 30 & 0.00 & 0.00 & 0.00 & 0.20 \\
11 & 33 & 0.00 & 0.00 & 0.00 & 0.00 \\
12 & 36 & 0.00 & 0.00 & 0.00 & 0.00 \\
13 & 39 & 0.00 & 0.00 & 0.00 & 0.00 \\
14 & 42 & 0.00 & 0.00 & 0.00 & 0.00 \\
15 & - & 144.71 & 106.45 & 69.39 & - \\
$\Sigma$ & & & & & \\
\hline
\end{tabular}


Table 4. Average metal content in technogenic placers formed in ravines and gullies for the consistency of the tuff hydro-mixture $L: S / 80 \%: 20 \%$

\begin{tabular}{cccccc}
\hline & Nength of placer, & \multicolumn{3}{c}{$\begin{array}{c}\text { Average mass of metal } \\
\text { in the core, } \mathrm{g}\end{array}$} & $\begin{array}{c}\text { Height of the } \\
\text { dump, } H, \mathrm{~m}\end{array}$ \\
\cline { 3 - 5 } & & $m_{1} 1.0 \%$ & $m_{2} 0.75 \%$ & $m_{3} 0.5 \%$ & \\
\hline 1 & 0 & 9.74 & 5.93 & 4.81 & 6.00 \\
2 & 3 & 43.40 & 19.30 & 16.42 & 6.00 \\
3 & 6 & 65.18 & 40.39 & 34.75 & 5.75 \\
4 & 9 & 31.31 & 29.25 & 13.90 & 5.00 \\
5 & 12 & 21.74 & 15.80 & 11.75 & 4.50 \\
6 & 15 & 9.85 & 12.20 & 4.96 & 3.75 \\
7 & 18 & 4.46 & 5.37 & 3.10 & 3.50 \\
8 & 21 & 4.25 & 3.62 & 1.52 & 3.25 \\
9 & 24 & 3.23 & 2.20 & 0.00 & 3.00 \\
10 & 27 & 1.07 & 0.00 & 0.00 & 2.50 \\
11 & 30 & 0.00 & 0.00 & 0.00 & 2.00 \\
12 & 33 & 0.00 & 0.00 & 0.00 & 1.50 \\
13 & 36 & 0.00 & 0.00 & 0.00 & 0.50 \\
14 & 39 & 0.00 & 0.00 & 0.00 & 0.00 \\
$\Sigma$ & - & 194.23 & 134.06 & 91.21 & - \\
\hline
\end{tabular}

Table 5. Generalized experimental data on the determination of the percentage of metal content in the core of technogenic placers in the ravine and gully

\begin{tabular}{|c|c|c|c|c|c|c|c|c|c|c|}
\hline \multirow{2}{*}{ No. } & \multirow{2}{*}{$\begin{array}{l}\text { Consistency } \\
\text { of hydro- } \\
\text { mixture, } \\
\text { L : S }\end{array}$} & \multirow{2}{*}{$\begin{array}{c}\text { Total } \\
\text { weight } \\
\text { of metal, } \\
m, \mathrm{~g} \\
\end{array}$} & \multirow{2}{*}{$\begin{array}{l}\text { Length of } \\
\text { the base, } \\
L, \mathrm{~m}\end{array}$} & \multirow{2}{*}{$\begin{array}{c}\text { Height } \\
\text { of the deposit, } \\
H, \mathrm{~m}\end{array}$} & \multirow{2}{*}{$\begin{array}{c}\text { Percentage } \\
\text { of metal in } \\
\text { experiments, } \%\end{array}$} & \multicolumn{3}{|c|}{$\begin{array}{c}\text { Metal content } \\
\text { in experiments, } g\end{array}$} & \multirow{2}{*}{$\begin{array}{c}\text { Metal content } \\
\text { in the core, } \\
m_{c}, \mathrm{~g}\end{array}$} & \multirow{2}{*}{$\begin{array}{l}\text { Metal } \\
\text { content in } \\
\text { the core, } \\
\text { in } \%\end{array}$} \\
\hline & & & & & & $m_{1}$ & $m_{2}$ & $m_{3}$ & & \\
\hline \multirow{3}{*}{1} & \multirow{3}{*}{$90: 10$} & 50.0 & 48.2 & 3.0 & 0.50 & 43.36 & 45.00 & 47.03 & 35.56 & 71.12 \\
\hline & & 75.0 & 48.8 & 3.0 & 0.75 & 60.25 & 73.27 & 72.25 & 51.82 & 69.09 \\
\hline & & 100.0 & 48.0 & 3.0 & 1.00 & 93.09 & 95.00 & 98.75 & 82.65 & 82.65 \\
\hline \multirow{3}{*}{2} & \multirow{3}{*}{$85: 15$} & 75.0 & 42.5 & 4.5 & 0.50 & 69.39 & 72.05 & 73.69 & 55.76 & 74.35 \\
\hline & & 112.5 & 42.1 & 4.5 & 0.75 & 106.51 & 109.12 & 103.13 & 87.98 & 78.20 \\
\hline & & 150.0 & 42.3 & 4.5 & 1.00 & 144.96 & 141.11 & 146.60 & 126.52 & 84.35 \\
\hline \multirow{3}{*}{3} & \multirow{3}{*}{$80: 20$} & 100.0 & 39.0 & 6.0 & 0.50 & 93.21 & 95.50 & 96.00 & 86.59 & 86.59 \\
\hline & & 150.0 & 39.1 & 6.0 & 0.75 & 134.27 & 140.05 & 144.24 & 122.87 & 81.91 \\
\hline & & 200.0 & 39.4 & 6.0 & 1.00 & 194.32 & 189.90 & 194.04 & 181.22 & 90.61 \\
\hline
\end{tabular}

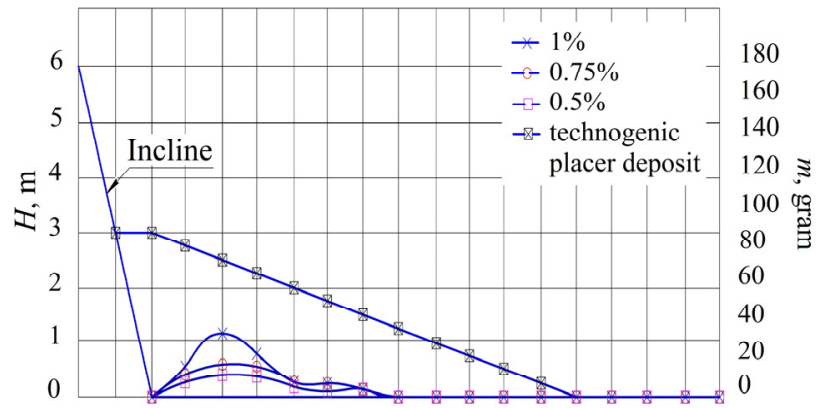

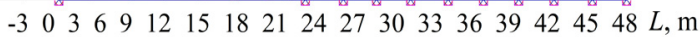
Consistency of hydro-mixture of tuff L:S / 90\%:10\% by weight of metal in the pulp

Figure 1. Determination of the technogenic placer core in ravines and gullies for the consistency of the tuff hydro-mixture $L: S / 90 \%: 10 \%$

The study described above confirms the hypothesis that the bulk of heavy particles and metal moves at the depth of one third of the pulp flow height in the bottom layer. While depositing to the bottom of the base, heavy particles form the placer core with the metal content percentage from 60 to $90 \%$.

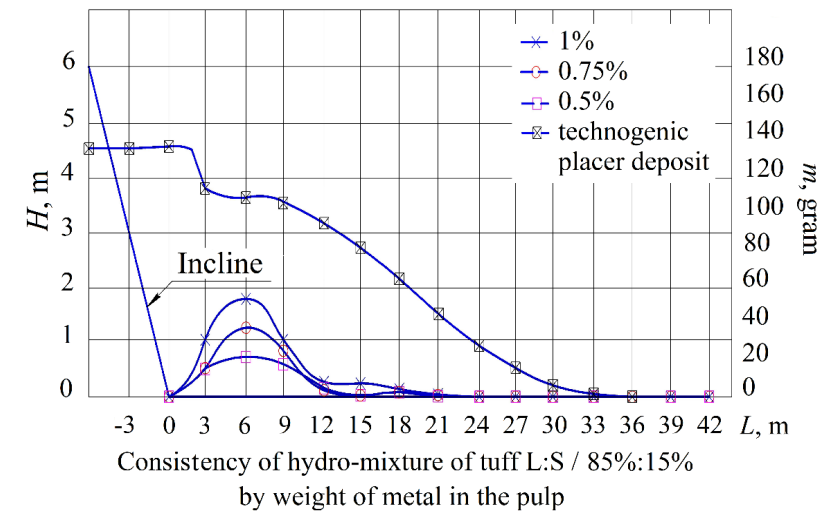

Figure 2. Determination of the technogenic placer core in ravines and gullies for the consistency of the tuff hydro-mixture $L: S / 85 \%: 15 \%$

Dusty, clayish and fine sandy particles of tuff move in the middle and surface layer of the pulp flow in the weighed state and form a technogenic placer. The maximum error in conducting the research does not exceed $10 \%$. 


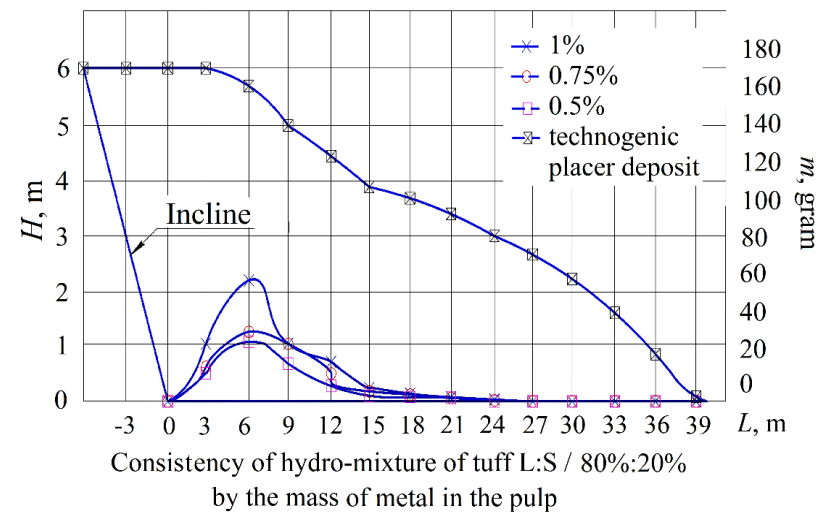

Figure 3. Determination of the technogenic placer core in ravines and gullies for the consistency of the tuff hydro-mixture $L: S / 80 \%: 20 \%$

Approximation and statistical processing of the research data were performed in MathCad and Microsoft Excel software packages. Experimental data were approximated by polynomials of the third order.

The polynomial approximation of the measurement data formed as a $Y$ vector at certain values of the argument which form the $X$ vector of the same length as the $Y$ vector, was carried out using the functions built into the MathCad for cubic spline-interpolation. The essence of splineinterpolation consists in the fact that for the intervals between the points, approximation is carried out in the form:

$f(x)=a x^{3}+b x^{2}+c x+d$,

where:

$a, b, c, d$-coefficients that are determined independently for each interval, based on $y_{i}$ values in adjacent points.

This process is hidden from the user, since the gist of the interpolation problem is to find the function $f(x)$ in any point $x$. Statistical data processing was performed to verify the accuracy of the approximation and quantitative evaluation. The value of the correlation coefficient and the mean square deviation between the experimental data and those calculated by means of the approximation dependencies were determined.

The correlation coefficient was obtained by the formula:

$r=\frac{\sum\left(x_{i}-x_{c p}\right)\left(y_{i}-y_{c p}\right)}{\sqrt{\sum\left(x_{i}-x_{c p}\right)^{2}\left(y_{i}-y_{c p}\right)}}$,

where:

$x, y$-experimental and estimated data respectively.

The mean square deviation was determined by the formula:

$$
\delta=\frac{\sqrt{\sum\left(x_{i}-y_{i}\right)^{2}}}{n-1},
$$

where:

$n$ - the number of measurement points.

To quantify reliability of the established mathematical dependences, the maximum relative error between the experimental results and the calculated values for each measurement point was determined: $y_{i}=\frac{x_{i}-y_{i}}{x_{i}} \cdot 100 \%$.

The dependences listed in Figures $1-3$ are described by the equation:

$$
H=f(L, m)=a(m) L^{3}+b(m) L^{2}+c(m) L+d(m),
$$

where:

$a(m), b(m), c(m), d(m)$ - the functions that are determined independently for each interval and characterize the dynamics of the placer core formation;

$m$ - mass fraction of metal in the placer;

$L$ - longitudinal placer coordinate.

Dependence (5) is the basis for the analytical construction of the predictive method for determining the dynamics of heavy metals core formation in the technogenic placer and its development in the gully and ravine.

The maximum average deviation is $10 \%$, the maximum relative error of calculation is $4.7 \%$.

\section{DISCUSSING THE RESULTS \\ OF THE RESEARCH INTO \\ THE FORMATION OF ZONES WITH INCREASED METAL CONTENT}

The configuration of the pulp flow in terms of free spreading on the slope corresponds to a parabola with the peak at the point of the pulp issuance. The core of the placer has an elongated configuration along the direction of the pulp movement to the spit-tank.

It has been experimentally proved that the maximum flight range of the pulp jet is achieved when the pulp line outlet is tilted to the horizon at an angle of $45^{\circ}$ (in fact, due to the influence of air resistance and dispersion, it reaches $30-35^{\circ}$ ). It is advisable, should the conditions allow, to position the outlet section of the pulp line as close to the edge of the slope or the basis of the placer as possible, under the condition of the least flow impact on the base. It is also necessary to try and ensure that the exiting flow reaches the bottom with its compact part. This condition most of all contributes to the formation of the heavy metals core in the slope bending point in the ravine and gully.

It is proved that minerals at the initial stage of technogenic placers formation are concentrated in the bottom of the plunge pool. As the height of the dump increases, heavy metals are accumulated in the core of the placer with the concentration of 60 to $90 \%$. The probability of an elastic impact of minerals on the cemented portions of the tuff, due to which minerals can be thrown out of the plunge pool contour, is negligible.

The research has established that the pulp issuance from the outlet of the distribution pulp line has a pulsating character and occurs either via full section, or after some time interval via a reduced cross section. Thus, the initial specific consumption and the initial rate of the pulp release during alluviation varies in time in absolute magnitude and along the front of the deposit. This phenomenon is one of the reasons for the undefined and nonuniform pulp flow along the deposit slope.

When the pulp is released through the end outlet on the alluviation map, it results in creation of a plunge pool, where the kinetic energy of the pulp stream 
decreases. The plunge pool plays a very important role in placer alleviation, especially in the pulp spreading and distribution along the deposit slope. Moreover, the plunge pool is not formed immediately, but with time. During the plunge pool formation, the tuff surface gets deformed due to the removal of the deposited tuff onto the placer base. It was established that the dimensions of the plunge pool (diameter and depth) vary in time due to the erosion and removal of previously alluviated, predominantly large, fractions, as well as coarse-grained tuff along the perimeter of the plunge pool. As a result of the change in the plunge pool size during the placer layer alluviation, there is also a change in the conditions of dispersion and distribution of the pulp on the deposit base, which greatly affects tuff spreading along the slope.

Halt in the movement of heavy, large and medium fractions and their precipitation on the deposit slope and along the length of the flow channel depends on the process of large fractions deposition. These fractions move in the bottom layer of the pulp flow. Therefore, the problems concerned with the height of the flow and its flight range are of great practical importance in determining the location of the plunge pool and the location of the placer core formation. Consequently, it is necessary to place the pulp line as close as possible to the edge, and to direct the flow parallel to the surface of the pulp discharge on the bottom of the placer base.

Parameters of zones with heavy metals high content in technogenic placers depend on the pulp concentration and the local landscape. In the site of placer formation, these parameters change according to the dependence described by the polynomial of the third order. The coefficients of the polynomial characterize the dynamics of the placer core formation, with heavy metals concentration from 60 to $90 \%$.

The investigations have established the regularities of heavy metals distribution in technogenic placers, which allows determining the location and calculating the parameters of zones with increased heavy metals concentration in the body of technogenic placers. Ideas about the mechanism of technogenic placers formation during their alluviation on the site with complex relief have been elaborated. The mathematical model of phase-by-phase formation of technogenic placers with zones of heavy metals concentration in metal-containing waste has been developed.

\section{CONCLUSIONS}

1. The conducted research has determined the parameters of metals concentration zones, depending on the density of the mixture and the method of placers formation on the site. Thus, it can be argued that the parameters of the zones with high metals content in technogenic placers depend on the pulp concentration and the terrain relief in the sites of placers formation.

2. The research allowed to establish regularities of metal distribution during formation of placers in the areas with complex relief - gully, ravine - with metal percentage content in the core from 60 to $90 \%$. This makes it possible to determine its location and calculate the parameters of the zones with increased metals concentration. The parameters of these zones are described by a polynomial of the third order, the coefficients of which characterize the dynamics of the placer core formation.

\section{ACKNOWLEDGEMENTS}

This work would have been impossible without the support of the National University of Water and Environmental Engineering and assistance in conducting experiments provided by the Institute of Geotechnical Mechanics named after M.S. Poliakov (National Academy of Sciences of Ukraine).

\section{REFERENCES}

Baiysbekov, S., Ospanova, G., \& Mozgovyh, G. (2006). Mining of Gold in Kazakhstan. Mining and Metallurgy in Kazakhstan, (II), 295-299.

Baranov, Yu.D., Bliuss, B.A., Semenenko, E.V., \& Shuryhin, V.D. (2006). Obhruntuvannia parametriv i rezhymiv roboty system hidrotransportu hirskykh pidpryiemstv. Dnipropetrovsk: Nova ideolohiia.

Brahyn, Yu. (2006). Resursna vartist tualetnoho zbahachennia ta hidrometalurhiinoi pererobky rud chornykh ta kolorovykh metaliv v Ukraini. Mineralni Resursy Ukrainy, (3), 16-19.

Bryantseva, O.S., \& Dubanov, V.G. (2011). The Environmental Accountability of Efficiency Evaluation of Processing Technogenic Formations. Economy of Region, 209-213. https://doi.org/10.17059/2011-2-25

Bullock, L., Parnell, J., Perez, M., Feldmann, J., \& Armstrong, J. (2017). Selenium and Other Trace Element Mobility in Waste Products and Weathered Sediments at Parys Mountain Copper Mine, Anglesey, UK. Minerals, 7(11), 229-248. https://doi.org/10.3390/min7110229

Cánovas, C.R., Macías, F., Pérez López, R., \& Nieto, J.M. (2018). Mobility of Rare Earth Elements, Yttrium and Scandium from a Phosphogypsum Stack: Environmental and Economic Implications. Science of the Total Environment, (618), 847-857. https://doi.org/10.1016/j.scitotenv.2017.08.220

Dozic, S., $\quad$ Djukic, M., $\quad$ Bogdanovic, G., $\quad$ Stanojlovic, R., Lukic, S., Djunisijevic-Bojovic, D., \& Bjedov, I. (2010). New Approach to the Reclamation of the Old Flotation Tailings in Bor. Glasnik. Sumarskog Fakulteta, (101), 35-47. https://doi.org/10.2298/gsf1001035d

Dychkovskyi, R.O., Lozynskyi, V.H., Saik, P.B., Petlovanyi, M.V., Malanchuk, Ye.Z., \& Malanchuk, Z.R. (2018). Modeling of the Disjunctive Geological Fault Influence on the Exploitation Wells Stability During Underground Coal Gasification. Archives of Civil and Mechanical Engineering, 18(4), 1183-1197. https://doi.org/10.1016/j.acme.2018.01.012

Dyusembaeva, K., \& Akkazyna, N. (2017). Tonkodispersnoe zoloto $\mathrm{v}$ rudakh zoloto-sulfidnogo mestorozhdeniya. Vestnik KazNTU, 2(59), 106-109.

Haletskyy, L., Petrova, L., \& Polska, L. (2004). Tekhnohenni vidkhody - potentsiyni dzherela utvorennia tekhnohennykh pokladiv. Visnyk Donetskoho Tekhnichnoho Universytetu, (1), 505-513.

Horlytskyy, B., Hubina, V., \& Turov, V. (2004). Tekhnohenni rodovyshcha: deyaki pryntsypovi osoblyvosti ta kryterii vyznachennia. Heokhimiia ta Ekolohiia, (9), 114-117.

Jha, M.K., Kumari, A., Panda, R., Rajesh Kumar, J., Yoo, K., \& Lee, J.Y. (2016). Review on Hydrometallurgical Recovery of Rare Earth Metals. Hydrometallurgy, (161), 77-101. https://doi.org/10.1016/j.hydromet.2016.01.003

Levei, E., Frentiu, T., Ponta, M., Tanaselia, C., \& Borodi, G. (2013). Characterization and Assessment of Potential Environmental Risk of Tailings Stored in Seven Impoundments in the Aries River Basin, Western Romania. Chemistry Central Journal, 7(1), 5-18. https://doi.org/10.1186/1752-153x-7-5 
Lozynskyi, V., Saik, P., Petlovanyi, M., Sai, K., \& Malanchyk, Ye. (2018). Analytical Research of the Stress-Deformed State in the Rock Massif around Faulting. International Journal of Engineering Research in Africa, (35), 77-88. https://doi.org/10.4028/www.scientific.net/JERA.35.77

Malanchuk, Z., Malanchuk, Y., Korniyenko, V., \& Ignatyuk, I. (2017). Examining Features of the Process of Heavy Metals Distribution in Technogenic Placers at Hydraulic Mining. Eastern-European Journal of Enterprise Technologies, $1(10(85)), 45-51$.

https://doi.org/10.15587/1729-4061.2017.92638

Mohamed, A.-M.O., \& Paleologos, E.K. (2018). Stability and Safety of Engineered Barrier Systems for Waste Containment. Fundamentals of Geoenvironmental Engineering, 361-421.

https://doi.org/10.1016/b978-0-12-804830-6.00011-9

Naduty, V., Malanchuk, Z., Malanchuk, Y., \& Korniyenko, V. (2016). Research Results Proving the Dependence of the Cop- per Concentrate Amount Recovered from Basalt Raw Material on the Electric Separator Field Intensity. Eastern-European Journal of Enterprise Technologies, 5(5(83)), 19-24. https://doi.org/10.15587/1729-4061.2016.79524

Onuaguluchi, O., \& Eren, Ö. (2012). Cement Mixtures Containing Copper Tailings as an Additive: Durability Properties. Materials Research, 15(6), 1029-1036. https://doi.org/10.1590/s1516-14392012005000129

Wang, S., Zhang, H., Zou, Z., Wang, P., \& Yu, T. (2015). Potential Risk Analysis of Tailings Dam under Preloading Condition and Its Countermeasures. Journal of Engineering and Technological Sciences, 47(1), 46-56. https://doi.org/10.5614/j.eng.technol.sci.2015.47.1.4

Yan-xia, L., Lei, Y., Ya-jun, C., Saud, S., Jing-jing, L., Hui, Y., \& Li-yuan Zhao. (2016). Landscape Transformation in Mining Wastelands. Journal of Northeast Agricultural University (English Edition), 23(1), 83-88. https://doi.org/10.1016/s1006-8104(16)30036-8

\section{МОДЕЛЮВАННЯ ПРОЦЕСУ УТВОРЕННЯ ЗОН КОНЦЕНТРАЦЇ̈ ПІДВИЩЕНОГО ВМІСТУ МЕТАЛУ В ТЕХНОГЕННИХ РОДОВИЩАХ}

\section{3. Маланчук, В. Корнієнко, Є. Маланчук, В. Сорока, О. Васильчук}

Мета. Дослідження умов утворення зон підвищеної концентрації металу та оцінка ймовірності його концентрації в ядрі у металовмісних розсипних техногенних родовищах за допомогою фізичного моделювання.

Методика. Дослідження проведені на моделі в лабораторних умовах із використанням вулканічного туфу Рафалівського кар'єру (Україна), що містить від 0.4 до 1.2\% самородної міді. Експериментальні зразки подрібнені на щоковому млині. Хімічний склад туфу встановлено спектральним аналізом. Гідросуміші виготовлені на електричному змішувачі та досліджені магнітним стержневим сепаратором типу СМС $0.5-1-\mathrm{MH}-0.2$, метал вилучався з магнітною індукцією 600 мТл. Апроксимація та статистична обробка дослідних даних проводилась у програмних пакетах MathCad та Microsoft Excel.

Результати. Експериментально доведено, що найбільша дальність польоту струменя пульпи досягається при нахилі вихідного оголовка пульповоду до горизонту під кутом $45^{\circ}$ (при впливі опору повітря його розсіювання становить $30-35^{\circ}$ ). Рекомендовано розташовувати вихідний переріз пульповоду якомога ближче до бровки укосу або основи розсипу з умови найменшої ударної дії струменя на основу. Встановлено, що розміри воронки розмиву - діаметр і глибина - змінюються у часі за рахунок розмиву та виносу раніше намитих переважно крупних фракцій, а також намиву крупнозернистого туфу по периметру воронки. Встановлено параметри зон підвищеного вмісту важких металів у техногенному розсипі, що залежать від концентрації пульпи та ландшафту місцевості (балка, яр), а у місці утворення розсипу дані параметри змінюються за залежністю, що описується поліномом третього ступеня. Коефіцієнти полінома характеризують динаміку формування ядра розсипу, де зосереджується від 60 до 90\% важких металів.

Наукова новизна. Встановлено основні фактори та закономірності розподілу важких металів у техногенних розсипах в процесі розмиву. Розроблена математична модель поетапного формування техногенного розсипу із зонами концентрації важких металів у металовмісних відходах.

Практична значимість. На основі отриманих результатів представляється можливим промислове освоєння металовмісних техногенних розсипів із виявленням зон максимальної концентрації металу. Вирішення проблеми переробки металовмісних відходів підвищить екологічну безпеку території та надасть підприємствам додатковий економічний ефект.

Ключові слова: металовмісні відходи, техногенне родовище, хвостосховище, гідросуміш, консистенція, концентрація металів

\section{МОДЕЛИРОВАНИЕ ПРОЦЕССА ОБРАЗОВАНИЯ ЗОН КОНЦЕНТРАЦИИ ПОВЫШЕННОГО СОДЕРЖАНИЯ МЕТАЛЛА В ТЕХНОГЕННЫХ МЕСТОРОЖДЕНИЯХ}

\section{3. Маланчук, В. Корниенко, Е. Маланчук, В. Сорока, А. Васильчук}

Цель. Исследование условий образования зон повышенной концентрации металла и оценка вероятности его концентрации в ядре в металлосодержащих россыпных техногенных месторождений при помощи физического моделирования.

Методика. Исследования проведены на модели в лабораторных условиях с использованием вулканического туфа Рафаловского карьера (Украина), содержащем от 0.4 до $1.2 \%$ самородной меди. Экспериментальные образцы измельчены на щековой мельнице. Химический состав туфа установлен спектральным анализом. Гидросмеси изготовлены в электрических смесителях и исследованы магнитным стержневым сепаратором типа СMC 0.5-1 MН-0.2, металл извлекался с магнитной индукцией 600 мТл. Аппроксимация и статистическая обработка опытных данных проводилась в программных пакетах MathCad и Microsoft Excel. 
Результаты. Экспериментально доказано, что наибольшая дальность полета струи пульпы достигается при наклоне выходного оголовка пульповода к горизонту под углом $45^{\circ}$ (при влиянии сопротивления воздуха его рассеивание составит $30-35^{\circ}$ ). Рекомендовано располагать выходное сечение пульповода как можно ближе к бровке откоса или основы россыпи из условия наименьшей ударного действия струи на основу. Установлено, что размеры воронки размыва - диаметр и глубина - изменяются во времени за счет размыва и выноса ранее намытых преимущественно крупных фракций, а также намыва крупнозернистого туфа по периметру воронки. Установлены параметры зон повышенного содержания тяжелых металлов в техногенной россыпи, зависящие от концентрации пульпы и ландшафта местности (балка, овраг), а в месте образования россыпи данные параметры изменяются по зависимости, описываемой полиномом третьей степени. Коэффициенты полинома характеризуют динамику формирования ядра россыпи, где сосредотачивается от 60 до 90\% тяжелых металлов.

Научная новизна. Установлены основные факторы и закономерности распределения тяжелых металлов в техногенных россыпях в процессе размыва. Разработана математическая модель поэтапного формирования техногенной россыпи с зонами концентрации тяжелых металлов в металлосодержащих отходах.

Практическая значимость. На основе полученных результатов представляется возможным промышленное освоение металлосодержащих техногенных россыпей с выявлением зон максимальной концентрации металла. Решение проблемы переработки металлосодержащих отходов повысит экологическую безопасность территории и позволит предприятиям получать дополнительный экономический эффект.

Ключевые слова: металлосодержащие отходы, техногенное месторождение, хвостохранилище, гидросмесь, консистенция, конщентрация металлов

\section{ARTICLE INFO}

Received: 14 September 2017

Accepted: 5 April 2018

Available online: 16 April 2018

\section{ABOUT AUTHORS}

Zinovii Malanchuk, Doctor of Technical Sciences, Professor of the Department of Development of Deposits and Mining, National University of Water and Environmental Engineering, 11 Soborna St, 33028, Rivne, Ukraine. E-mail: malanchykzr@ukr.net

Valerii Korniienko, Candidate of Technical Sciences, Associate Professor of the Department of Development of Deposits and Mining, National University of Water and Environmental Engineering, 11 Soborna St, 33028, Rivne, Ukraine. E-mail:kvja@mail.ru

Yevhenii Malanchuk, Doctor of Technical Sciences, Associate Professor of the Department of Automation, Electrical Engineering and Computer-Integrated Technologies, National University of Water and Environmental Engineering, 11 Soborna St, 33028, Rivne, Ukraine. E-mail: malanchykez@mail.ru

Valerii Soroka, Candidate of Agricultural Sciences, Associate Professor of the Department of Transport Technologies and Maintenance, National University of Water and Environmental Engineering, 11 Soborna St, 33028, Rivne, Ukraine. E-mail: vssoroka@i.ua

Oleksandr Vasylchuk, Candidate of Technical Sciences, Associate Professor of the Department of Development of Deposits and Mining, National University of Water and Environmental Engineering, 11 Soborna St, 33028, Rivne, Ukraine. E-mail: o.y.vasylchuk@nuwm.edu.ua 